\title{
The Triple Intervention: A Forgotten Memory in the Discourse of the Nineteenth Century's International Law
}

\author{
Bijun $\mathrm{Xu}^{*}$
}

The 19th century's international law distinguished civilized from non-civilized States resulting in any country desiring equal treatment was required to obtain recognition from those already deemed civilized. Japan was able to join the civilized world by presenting a civilized image of itself in the First Sino-Japanese War, which was depicted by Western legal scholars as a clash between barbarism and civilization. Neither Japanese nor Western scholars of international law, however, have touched on the issue of the Triple Intervention. This incident serves as a case study for re-evaluating the operation of Western countries' international legal standards. The argument is, that these countries cloak their motives in legal language for self-aggrandizement, thereby demonstrating the ahistorical nature of the West's rhetoric of civilization. Further, this incident taught Japan the lesson that international law is concerned not with morality but with power.

\section{Keywords}

The Triple Intervention, 19th century's International Law, Discourse of Civilization, Japan, First Sino-Japanese War

* Post-doctoral Researcher at Tsinghua University, China. LL.B. (Tsinghua), LL.M. (UMich), Ph.D. (HKU). ORCID: https://orcid.org/0000-0002-0104-8749. This article is revised and updated version of Chapter VII of the author's doctoral dissertation submitted to the graduate committee of the University of Hong Kong. This work was supported by China Postdoctoral Science Foundation. The author may be contacted at: xubijun@mail.tsinghua.edu.cn/Address: School of Public Policy and Management, Tsinghua University, Beijing 100084 P.R. China. DOI: http://dx.doi.org/10.14330/jeail.2018.11.2.06 


\section{Overview}

On April 23, 1895, the Ministers of Russia, Germany, and France visited Japanese Vice Minister Hayashi at the Foreign Ministry in Tokyo. Based on instructions from their respective governments, each presented an objection against the article regarding the cession of the Liaotung Peninsula to Japan under the terms of the Treaty of Shimonoseki that ended the Sino-Japanese War. ${ }^{1}$ The three memoranda were identical in substance but worded differently. The German proposal was the most forceful; it included phrasing that directed Japan to accept the recommendation because it could not prevail in a war against the three European countries. France's proposal was the most moderate. ${ }^{2}$ In each case, Japanese possession of the Liaotung Peninsula was described as a situation that "would be a constant menace to the capital of China, would at the same time render illusory the independence of Korea, and would henceforth be a perpetual obstacle to the peace in the Far East."3

In addition to applying diplomatic pressure, these countries showed their determination militarily. Russia had an imposing naval force in Chinese and Japanese coastal waters, with thirty warships in the Pacific when the treaty was ratified. ${ }^{4}$ St. Petersburg issued secret orders to all Russian warships anchored in Japanese ports to be ready to set sail on twenty-four hours' notice. ${ }^{5}$ In the telegram to Mutsu, Minister Nishi warned: "It is said that lately [the] Russian Government [has] give[n] some transports and [is] preparing to [move to] Odessa for the dispatch of troops. It would be much safe[r] to consider [that] their intervention will be serious."

Germany was equally prepared to resort to force. ${ }^{7}$ When approached by Japan,

1 Morinosuke Kajima, The Diplomacy of Japan 1894-1922. Volume I: Sino-Japanese War and Triple Intervention 293 (1976).

2 Id. at 294. See also Telegram from Mr. Trench to the Earl of Kimberley, Subject: Three-Power Intervention, 24 April 1895 (Doc. 377, 6706/137), in British Documents on Foreign Affairs-Reports and Papers from the Foreign Office Confidential Print. Part I, From the Mid-Nineteenth Century to the First World War. Series E, Asia (vol.18601914), 5: Sino-Japanese WAR And Triple InTERVENTION 1894-1895, 226 (I. Nish ed., 1989).

3 S. Paine, The Sino-Japanese War of 1894-1895: Perceptions, Powers, and Primacy 287 (2003).

4 Id. at 286 .

5 Doc 371, Telegram from Mr. Trench to the Earl of Kimberley, Subject: Russian Naval Preparations, 23 April 1895, in British Documents, supra note 2, at 224. See also Mutsu Munemitsu, Kenkenroku: A Diplomatic Record of the SinoJAPANESE WAR, 1894-1895 205 (G. Berger ed. \& trans., 1982).

6 Telegram from Minister Mishi in St. Petersburg to Mutsu on April 27, in JAPANESE Diplomatic Documents (NGB) [日 本外交文書]: (MeiJ ERA SupplemENT), BK 1, No 714, recited from supra note 1, at 304.

$7 \quad I d$. at 329 . 
Berlin was found to be acting in co-operation with St. Petersburg. ${ }^{8}$ Meanwhile, Mutsu tried to ascertain whether Russia might reconsider its recommendation. Japan acted as it had before the war, asserting that the cession under the treaty would not threaten Russian interests in the Far East and that Russian concerns regarding Korean independence would be satisfied. ${ }^{9}$ Russia, however, refused Japan's request to reconsider. ${ }^{10}$ At the same time, Mutsu inquired of its ministers in the UK, the US, and Italy to canvas their support for Japan. ${ }^{11}$

However, their responses were not promising either, both the UK and the US flatly refused to intervene and were determined to remain neutral. ${ }^{12}$ London warned that Russia was fully prepared to persist in its land. ${ }^{13}$ The US could only support Japan within the bounds of its neutrality, advising China to proceed with ratification of the treaty. ${ }^{14}$ Italy, unexpectedly, kept counsel with the UK and the US and showed its resolution to confront the three other European powers. Nonetheless, Japan, based on its experiences with the former two countries, was not looking for much from Italy, either. ${ }^{15}$

Mutsu eventually had to conclude that Japan could not "think of any means but to compromise with Russia, Germany, and France, by accepting a part or the whole of their recommendation." 16 The Japanese government accordingly introduced two modifications into the treaty and presented a memorandum on the abandonment of Liaotung to the three governments. The modifications were as follows:

First.-The Imperial Government consent to renounce their definitive possession of the Fengt'ien Peninsula, excepting the province of Kinchow, reserving for subsequent adjustment with China the question of a reasonable pecuniary compensation for the abandoned territory. Second.-It is, however, understood that the Imperial Government shall have the right to occupy as a guarantee the above-mentioned territory pending

8 Munemitsu, supra note 5, at 246.

9 Instructions by telegram from Mutsu to Minister Nishi, in NGB: Vol 28, Bk 2, No 698, recited from supra note 1, at 302.

$10 \mathrm{NGB}, \mathrm{BK}$ 1, No 714, recited from supra note 1, at 304.

11 Instructions from Mutsu to Minister Kato in London, in NGB: Vol 28, Bk 2, No 710; Instructions from Mutsu to Minister Kurino in America, in NGB: Vol 28, Bk 2, No 711, recited from supra note 1, at 302-4, 343. See also MunEmitsu, supra note 5, at 211-2.

12 Statement from the British Foreign Secretary to Kato on April 29, in NGB: Vol 28, Bk 2, No 746 and Telegram from Minister Kurino to Mutsu on April 29, in NGB: Vol 28, Bk 2, No 716, recited from supra note 1, at 305.

13 Munemitsu, supra note 5, at 212.

14 Id. at 213.

15 Supra note 1 , at 306.

16 Id. at 307. 
the complete performance by China of her Treaty engagements to Japan. ${ }^{17}$

Germany and France were inclined to accept certain modifications, while Russia was unsatisfied with this memorandum. It insisted on the original recommendation that Japan not be allowed to occupy any Chinese territory. ${ }^{18}$ Mutsu at this point judged that it was time to accede entirely to the three powers' demands. ${ }^{19}$ When Mr. Trench, the Japanese Minister to the UK, asked why Japan had given in to the 'friendly advice' of the Triple Intervention, Minister Hayashi responded: "When Japan saw thirty Russian vessels of war assuming a threatening attitude and a state of siege declared at Vladivostok, and her own army and navy exhausted by a year's fighting and cholera making havoc amongst the men, what alternative had she? ${ }^{20}$ What he said was true! France and Russia had consistently acted as if their communications were friendly warnings, but no mere friendly remonstrance would have had such an effect on Japan. It was clear to all that the three powers would use force if Japan failed to heed their warnings. ${ }^{21}$ Thus, according to a telegram sent by Consul Allen to Mr. O'Conor, all of the Russian ships were prepared for action. Had Japan refused to accept their 'friendly advice,' the Russians would have launched an immediate attack on the Japanese fleet at Ta Lien Wan. Additionally, instructions had been sent by telegraph to a Russian merchant steamer, the Wladimir that was in the harbor calling for the immediate discharge of any Japanese nationals among its crew. Three German craft-the flagship Irene, the corvette Marie, and the gunboat Iltis-were also in port, as was a French corvette, the Forfait. ${ }^{22}$

On May 4, 1895, Japan finally agreed to follow the advice of Russia, Germany, and France, which expressed their satisfaction with its decision on May $9 .{ }^{23}$ On November 8, the Convention on the Retrocession of Liaotung and Protocol was signed by Minister Hayashi, Plenipotentiary of Japan, and Li Hung-chang, Plenipotentiary of

17 Doc 443, 6706/201, Memorandum Communicated to the Foreign Office by Mr. Kato, Subject: Japan's Reply to Interventionist Powers, 2 May 1895, in British Documents, supra note 2, at 263. See also M. IKō, Posthumous Manuscripts of Count Munemitsu Mutsu 5-9 (1929), in NGB: Vol 28, Bk 2, No 748, recited from supra note 1, at 308.

18 Munemitsu, supra note 5, at 216.

19 Id. at 309.

20 Doc 654, 6706/397, Despatch from Mr. Trench to the Earl of Kimberley, Subject: Reasons for Japan's Concessions, 9 May 1895, in BRITISH DocumenTs, supra note 2, at 366.

21 Doc 482, 6706/236, Telegram from Mr. Trench to the Earl of Kimberley, Subject: Background to Retrocession, 8 May 1895 , in BRITISH DOCUMENTS, supra note 2, at 280.

22 Doc 710, 6706/452(i), Despatch from Consul Allen to Mr. O'Conor, Subject: Ratifications Exchanged, 7 May 1895, in BRITISH Documents, supra note 2, at 409.

23 Munemitsu, supra note 5, at 218. 
China, which was finally ratified on November $29 .{ }^{24}$ On November 16, in London, the Chinese Government paid Japan 30 million taels in compensation for the return of the Liaotung Peninsula and Japan completed the retrocession on December 23 and evacuated the last of its troops on December $25 .^{25}$

This historical incident is deeply affiliated with the late 19th century's development of international law; bridging the gaps between Euro-centricism and the importance of a global discourse in a real sense. The primary purpose of this research is to make up for the missing historical discourse and to re-evaluate the actual operation of international legal standards of the West in light of the Triple Intervention. Then, the author will show the ahistorical approach to international law based upon the definition of a so-called 'civilization' in light of the historic turning point for the Japanese, in the understanding of Western civilization and international law. This paper is composed of four parts including this Introduction and Conclusion. Part two will review the Triple Intervention in light of the power balance theory and the 19th century's international law. Part three will examine the influence of the Triple Intervention on Japan.

\section{The Triple Intervention, the Balance of Power and the Nineteenth Century's International Law}

Germany, France, and Russia intervened in Japan's annexation of the Laotung Peninsula, because it posed a threat to the Chinese capital and to Korean independence. ${ }^{26}$ The Triple Intervention, in other words, maintained the status quo by constraining Japan's rapid expansion, particularly toward China and Korea. The cession of the peninsula finally restored the balance of power in the region. The following discussion will examine if the balance of power is a useful doctrine of international law to justify the Triple Intervention.

\section{A. The Triple Intervention from the Perspective of the Balance of Power}

According to Kaplan and Katzenbach's theory, the balance of power in the international system requires that the relationship among nations be "competitive, suspicious, and

\footnotetext{
24 For the full text of the Convention of Retrocession, see supra note 1, at 382.

25 NGB, Vol 28, Bk 2, No 1219 and after, recited from supra note 1, at 385.

26 Supra note 3, at 287.
} 
primarily instrumental." ${ }^{27}$ Political interests and expediency must be the paramount goal of each nation for its own security. Kaplan and Katzenbach addressed:

Since changes in national productivity of an unexpected nature might disturb the 'balance,' each nation strives to gain security and to prevent any other nation from becoming too strong to be a serious threat. For these reasons, nations will enter coalitions to gain prizes of some sort or another, such as territory, resources, shipping facilities, and so forth. ${ }^{28}$

Such was the case with the First Sino-Japanese War and the subsequent Triple Intervention. At the beginning of the war, the European powers did not consider Japan a threat, nor did they think that the war would seriously damage their interests or disturb the balance of power in the region. However, Japan's rapid dominance over China far exceeded European expectations. Finally, their fears intensified after recognizing Japan's ambition to control both Korea and China. ${ }^{29}$ Russia was particularly concerned because Japan's sphere of influence then extended right up to its border. According to Kaplan and Katzenbach, Russia, Germany, and France entered into a coalition to gain the prize of a weakened Japan and to increase power for themselves. ${ }^{30}$

While considering joint forces, the three powers were also suspicious of the balance of power among themselves. For example, the UK feared that Russia would emerge as its primary enemy in the near future; ${ }^{31}$ while Germany and Italy planned to stand on opposite sides to prevent the triple intervention from becoming too strong. Every nation within the international power balance system felt insecure and suspicious of the others, irrespective of whether it was part of an alliance. ${ }^{32}$

29 The Russian Government recognized that the victory of Japan would be far more serious than it had anticipated. See IKō, supra note 17, at 524-5, recited from supra note 1, at 313. See also Doc 279, 6706/30, Telegram from Sir. F. Lascelles to the Earl of Kimberley, Subject: Russia Opposed to Terms, 5 April 1895, in BrITISH DocumEnTS, supra note 2, at 175; Doc 367, 6706/117, Despatch from Sir E. Monson to the Earl of Kimberley, Subject: Austrian Attitudes, 18 April 1895, in BRITISH Documents, supra note 2, at 222. At the same time, the commercial concessions Japan had received from China would be fatal to the commerce of all European nations within China because Japan would obtain a complete monopoly, and European goods would not be able to be imported into China. See Doc 431, 6706/183, Despatch from Sir F. Lascelles to the Earl of Kimberley, Subject: France and Peace Terms, 23 April 1895, in BRITISH DOCUMENTS, supra note 2, at 258.

30 Supra note 27, at 32.

31 The UK came to regard Russia as more of an enemy than Japan in this region, so that it would not offer Russia any facilities in China or the Far East. See supra note 1, at 321.

32 Supra note 27 , at 32 . 
Mearsheimer's theory of 'offensive realism' is useful to understand in this respect. Because States regard each other with suspicion and anticipate danger, he argues that they seek to shift the balance of power in their own favor or to prevent other States from shifting it to their detriment. ${ }^{33}$ According to Mearsheimer's theory, the First Sino-Japanese War broke out on hegemony over Korea. ${ }^{34}$ Thus Japan, having defeated China, began searching for opportunities to expand its influence; creating suspicion and security concerns among other great powers. ${ }^{35}$ The Russo-Japanese War (1904-05) further manifested the rivalry between them for regional control. Considering Russia a potential enemy, the UK established an alliance with Japan, ${ }^{36}$ while the US sought to constrain Japan's growing power by keeping Russia strong. ${ }^{37}$

Another characteristic of the balance of powers system was that coalitions would be fragile and short-term because they are designed for pressing "immediate and short-term" interests. ${ }^{38}$ Kaplan and Katzenbach maintained: "If too successful, such a coalition might eliminate defeated nations and thus threaten the interests of the weaker members of the successful coalitions, whose security would then become precarious. ${ }^{39}$ Various issues may give rise to differing alignments. Previously uncommitted nations or even members of an established coalition would oppose the dominant alliance. ${ }^{40}$ As far as their national interests allow, hegemonic powers restrained themselves when dealing with an opposite party shortly for possible future cooperation. ${ }^{41}$

This was the situation surrounding the Triple Intervention. In fact, France was more sincere than Russia and Germany. Before the Triple Intervention, French Minister Harmand in Tokyo had spoken repeatedly of the desirability of a FrancoJapanese alliance, cautioning Japan regarding Russia's intentions. Even in the midst of the joint intervention, France never attempted to curry favor with Russia as

33 J. Mearsheimer, The Tragedy of Great Power Politics 138 (2001).

34 Article 1 of the Treaty of Shimonoseki provides China's recognition of the independence of Korea without mentioning Japan. This article ended the tributary relationship between China and Korea and meant that Korea would become award of Japan, not China. See id. at 177.

35 Id. at 172-9. See also supra note 3, at 324.

36 The Anglo-Japanese Alliance was signed by Lord Lansdowne (British foreign secretary) and Hayashi Tadasu (Japanese minister in London) on January 30, 1902 to challenge and limit Russian power in the region. See D. BuRTON, CECIL SPRING Rice: A Diplomat's Life 100 (1990).

37 Supra note 33, at 178.

38 Supra note 27, at 32-5.

$39 \quad$ Id. at 32.

40 Id.

41 Id. 
Germany did. ${ }^{42}$ In the end, Harmand acknowledged Japan's correct perception in French position during the intervention under the prevailing circumstances. ${ }^{43}$

Another example of the fragility of the alliance was the serious divergence between Germany and Russia during the intervention. When Japan first replied to the protest of the three powers, Russia refused to accept Japan's conditions, while Germany found the conditions were quite reasonable. ${ }^{44}$ Russia was suspicious of Germany, even concluding that it had secretly emboldened Japan in the formulation of the conditions. ${ }^{45}$ In a telegram, the French Minister to Russia reported that Russia had once asked France to replace Germany with a different alliance partner. ${ }^{46}$ Germany regarded the Russian loan to China as an act of self-aggrandizement. According to Baron von Marschall, a certain share of this loan had been reserved for a group of German financiers, but it turned out that Germany would have derived no benefit from the transaction. ${ }^{47} \mathrm{Mr}$. Gosselin stated in his telegram to the Earl of Kimberley that "from the whole tone of his Excellency's observations, I think it may be safely assumed that the joint action of the three Powers in the Far East is already a thing of the past." ${ }^{, 48}$ More examples could be cited of the fragile, short-term, and conflicting interests that have characterized coalitions under the balance of power system. ${ }^{49}$ The UK did not stand with the three powers in the intervention. The British Minister in Berlin assured Japanese Minister Aoki that his country would neither allow Russia to take control of Port Lazarev, and nor would Germany and France, for if that happened, the conflicting interest would be turned..$^{50}$

42 Munemitsu, supra note 5, at 244.

43 Id.

44 Id. at 216.

45 N. À Hanotaux, 24 juillet 1895, Documents Diplomatiques Français (1871-1914), 1ére série, Tome 12, Paris: Imprimerie nationale 135 (1947), recited from Fuping Ge, France and the First Sino-Japanese War, 3 Soc. Sci. IN CHINA 198 (2013) <available only in Chinese>.

46 Id.

47 Doc 694, 6706/424, Despatch from Mr. Gosselin to the Earl of Kimberley, Subject: German Attitudes, 14 June 1895, in BRITISH DoCuments, supra note 2, at 399.

48 Id.

49 For example, France viewed the joint intervention as a good chance to consolidate the Franco-Russian alliance and to cope with the state of being isolated in Europe, especially the diplomatic pressure from the tripartite pact of Germany, Austria-Hungary and Italy. See supra note 45, at 202. At the same time, the Kaiser aimed to demonstrate that Germany was able to provide Russia with more support in the Far East than France. See Doc 298, 6706/51, Telegram from Sir F. Lascelles to the Earl of Kimberley, Subject: Russia Regrets Britain's Refusal, 10 April 1895, and Doc 472, 6706/223, Despatch from Sir E. Malet to the Earl of Kimberley, Subject: Germany's Attitude, 4 May 1895, in British DocumENTS, supra note 2 , at $182 \& 277$.

50 Doc 474, 6706/225, Despatch from Sir E. Malet to the Earl of Kimberley, Subject: Viscount Aoki’s Views, 5 May 1895, in BRITISH DOCUMENTS, supra note 2, at 278. 


\section{B. The Balance of Power and International Law}

The balance of power doctrine has been an important political idea since the Peace of Westphalia in $1648 .^{51}$ It became a foundational principle of the modern law of nations as part of the Utrecht Peace Treaties in the 1710s that put an end to the War of Spanish Succession, one of the most devastating armed conflicts in modern Europe. ${ }^{52}$ Then, in the 1810s, the settlement of the Vienna Congress and the Congress of Aix-la Chapelle gave rise to the "system of consultation between the Great Powers known as the Concert of Europe." ${ }^{\text {"53 }}$ This agreement played an influential role in maintaining and adjusting a balance of power on which European peace could rest for the coming century. ${ }^{54}$ However, as the periphery of Europe developed, maintaining power balance among nations became more complicated and "the mechanics of the balance system" finally collapsed with the outbreak of World War I in $1914{ }^{55}$

In terms of the interrelationship between the balance of power and law, Alfred Vagts and Detlev Vagts, after carefully studying the publicists' thoughts from 1648 to 1914 , conclude that the views were never unanimous. ${ }^{56}$ Some scholars argued that preserving the balance could be an excuse to intervening into other States' domestic affairs under international law. ${ }^{57}$ British jurist Robert Phillimore, for example, regarded the balance of power as a determinant of international law, asserting that intervention was appropriate when an "existing Power acquires an aggrandizement that may menace the liberties of the rest of the world." ${ }^{, 58}$ Even German Jurist Lassa P. Oppenheim, who rejected the view that the balance of power is a principle of international law, ${ }^{59}$ nevertheless considered it "an indispensable condition of the very existence of international law." ${ }^{60} \mathrm{He}$ further argued: "Intervention in the interests of the balance of power must be excused, and that it is a matter of appreciation for every

51 L. Gross, The Peace of Westphalia, 1648-1948, 42 Am. J. INTL L. 27-8 (1984).

52 L. Oppenheim, International Law: A Treatise (1905). See also T. Twiss, The Law of Nations Considered as Independent Political Communities, on the Rights and Duties of Nations in Time of Peace (2d ed. 1884), recited from R. Lesaffer, The Peace of Utrecht and the Balance of Power, Oxford Public International Law, available at http://opil. ouplaw.com/page/utrecht-peace/The-Peace-of-Utrecht-and-the-Balance-of-Power (last visited on Nov. 2, 2018).

53 Supra note 51 , at 20.

54 Id.

55 A. Vagts \& D. Vagts, The Balance of Power in International Law: A History of an Idea, 73 Am. J. INTL L. 567 (1979).

56 Id. at 555 .

57 Id.

58 R. Phillimore, 1 Commentaries on International Law 489 (2d ed. 1871), recited from id. at 569.

59 L. Oppenheim, International Law 193 (2d ed. 1912), recited from B. Kingsbury, Legal Positivism as Normative Politics: International Society, Balance of Power and Lassa Oppenheim's Positive International Law, 13 Eur. J. InTL. L. 417 (2002).

60 Oppenheim, $i d$. at 193 , recited from supra note 55 , at 570. 
State whether or not it considers the balance of power endangered and intervention necessary." $" 61$

Others discussed the concept of 'paradox' in the sense of the relationship between the power balance theory and international law. Moorhead Wright, for example, acknowledged that maintenance of the power balance might entail interference in the domestic affairs of various States to prevent a destabilizing increase in power. Nevertheless, he observed that doing so seemed to violate the independence that was the principal objective of international law. ${ }^{62}$ Hedley Bull found a paradoxical situation in which the balance of power could be viewed as an "essential condition of the operation of international law," but its maintenance would "often involve violation of the injunctions of international law." Rather than abandoning the theory, however, Bull appears to have accepted this paradox as "a normative problem related to the difficulties in regulating of power within international society." ${ }^{\circ 4}$ In his assumption, violations of particular injunctions of international law would not affect the operation of the international system as a whole, so that the relationship between the balance of power and international law generally is independent. ${ }^{65}$ From this perspective, even the violations of particular international laws are justifiable if they contribute to international peace, stability and "freedom necessary for the independence of each nation.,

On the basis of such arguments, the Triple Intervention could be considered justifiable, because, according to the public statements of the three powers, ${ }^{67}$ their combined action helped to maintain the balance of power and regional stability. According to the discussion so far, the logic that guided States' declarations of intent was distinct from that which guided their actual policy-making. Indeed, the three powers' subsequent behavior further showed that their intervention had neither protected China nor Korean independence; neither peace nor stability were brought to the region. By forcing Japan to sign the Convention of Retrocession with China, the three powers began to seize and partition the territory won by Japan during the war. China was fully aware that its European champions would ask for 'recompense' for

61 Supra note 59 , at 417.

62 M. Wright, The Theory and Practice of the Balance of Power: Selected European Writings xvii (1975), recited from R. Hjorth, Hedley Bull's Paradox of Balance of Power: A Philosophical Inquiry, 33 Rev. InT'L. Stud. 600 (2007).

63 H. Bull, The Anarchical Society: A Study of Order In World Politics 194 (4th ed. 2012), recited from supra note 62 , at 598 .

64 Id. at 597.

65 Id. at $597 \& 608$.

66 Id. 610-1.

67 Supra note 3, at 287. 
their efforts in one form or another. ${ }^{6}$

Russia was then prepared to undertake financial administration of China. ${ }^{69}$ On June 3, 1896, China and Russia signed the Li-Lobanov Treaty, also known as the SinoRussian Secret Treaty. The terms of this treaty, which were not open to public for over a quarter century, provided for the annexation of northeast China by Russia in all but name. ${ }^{70}$ Rather than protecting China from Japanese territorial ambitions, the treaty paved the way for further Russian expansion in the form of the Russia-Qing Convention of 1898, which compelled China to lease the southern tip of the Liaotung Peninsula to Russia in order to build China Eastern Railway connecting northern Harbin to the port city of Dalian. ${ }^{71}$

Meanwhile, the German Minister demanded a similar concession at Hankow as the British demanded in addition to the freedom of missionaries that had been refused to M. von Brandt, the German envoy in China (1875-93). ${ }^{72}$ Two years later, Germany secured control over Shandong Province. In November 1897, two German Roman Catholic priests were murdered in southern Shandong, which provided an opportunity to dispatch an entire squadron immediately to Kiautschou. ${ }^{73}$ Negotiations were opened for the Chinese government, and on March 6, 1898, the German Empire backed away from its demand for the outright cession of the area and accepted a leasehold on the bay for ninety-nine years. One month later, a treaty was ratified, and Kiautschou Bay was placed officially under German protection. ${ }^{74}$

Both the Russians and the Germans kept their eyes on Chinese territory. The French Minister was pressing China for rectifying an agreement regarding the Tonquin-Yunnan frontier. ${ }^{75}$ Even the Spanish government sought to make a group

68 Doc 705, 6706/449, Despatch from Mr. O'Conor to the Earl of Kimberley, Subject: Formosa, 8 May 1895, and Doc 478, 6706/232, Telegram from The Earl of Kimberley to Mr. O’Conor, Subject: Background to Retrocession, 7 May 1895 , in BRITISH DoCUMENTS, supra note 2, at 279 \& 406.

69 Doc 481, 6706/235, Telegram from Mr. O’Conor to the Earl of Kimberley, Subject: Possible Concessions from China, 8 May 1895, in BRITISH Documents, supra note 2, at 280.

70 R. Kowner, Historical Dictionary of the Russo-Japanese War 209 (2006).

71 E. Schumpeter, The Industrialization of Japan and Manchukuo, 1930-1940: Population, Raw Materials and INDUSTRY 382 (1940).

72 Doc 705, 6706/449, Despatch from Mr. O'Conor to the Earl of Kimberley, Subject: Formosa, 8 May 1895, and Doc 481, 6706/235, Telegram from Mr. O’Conor to the Earl of Kimberley, Subject: Possible Concessions from China, 8 May 1895, in BRITISH DocumeNTS, supra note 2, at 406.

73 T. Gottschall, By Order of the Kaiser: Otto von Diederichs and the Rise of the Imperial German Navy 1865-1902, 157 (2003).

74 Id. at $176-7$.

75 Doc. 481, 6706/235, Telegram from N.R. O'Conor to the Earl of Kimberley, Subject: Possible concession from China, 8 May 1895, in British Documents, supra note 2, at 280. See also QINGJ WaiJaO Shiliao, Vol. 106 13, Vol. 111 23, Vol. 1129 (Yanwei Wang \& Liang He eds., 1932) <available only in Chinese>, recited from supra note 45, at 194-5. 
of small islands to the southeast of Formosa its protectorate. ${ }^{76}$ Russia, France, and Germany for their part viewed this action favourably, though the German ambassador at first attempted to make the promise of a satisfactory commercial treaty conditional. $^{77}$

These events make clear that a positive assessment to the doctrine of power balance considering individual States' public declarations as accurate reflections of their will and thinking, is misguided. In fact, for the European powers, maintenance of the power balance was more than intervention, as a tool or excuse to pursue their own interests. No wonder, other scholars may have discussed the balance of power in a more realistic manner consistent with States' practices.

To begin with, Hugo Grotius suspiciously viewed power balance as a justification to take up arms to weaken a growing power as a potential threat to peace and stability. ${ }^{78}$ Johann Moser was similarly skeptical, considering the power balance as nothing more than a cloak for the private intentions of individual sovereigns. ${ }^{79}$ Heinrich Oppenheim likewise insisted "that actions taken to preserve the equilibrium" among States be strictly limited, so that parties that have not been directly attacked lack "a basis for declaring war," though they may assist "the weaker of the parties to the conflict." ${ }^{, 00}$ More critically, Johann Klueber and Karl von Kaltenborn opined that the system is simple politics rather than an institution of international law. ${ }^{81}$ Along the same lines, Richard Cobden "labelled the power balance as a 'chimera' and 'fallacious"' on the grounds that it neither limits the territorial claims of the great powers, nor contributes to the independence of small nations but rather secures the privileges of the former. ${ }^{82}$ Accordingly, he called for the foundation of the international society based on the principle of non-intervention under any circumstances. ${ }^{83}$

76 The Spanish Government once informed the Earl of Kimberly that it was much disquieted by the cession of the island to Japan owing to its proximity to the Philippines. See Doc 510, 6706/262, Despatch from The Earl of Kimberley to Sir H. Drummond Wolff, Subject: Spain and Formosa, 14 May 1895, in British DocumenTs, supra note 2, at 294.

77 Doc 590, 6706/339, Telegram from Sir H. Drummond Wolff to the Earl of Kimberley, Subject: Spanish Pretension to Island Group, 1 June 1895, in Nish, in British DocumenTs, supra note 2, at 334.

78 H. Grotius, 2 Dejure Belli Ac Pacis Libri Tres 173-5 (trans. F. Kelsey 1925), recited from supra note 55, at 560.

79 Grund-SÄtze Des Jetzt Üblichen EuropÄIschen VÖlKer-Rechts In FriedEns-Zeiten 58-60 (1763), recited from supra note 55 , at 563 .

80 H. Oppenheim, System Des VÖlkerrechts 27-33, 42 \& 272-76 (1845), recited from supra note 55, at 566.

81 J. Klueber, Droit Des Gens Modern De L Europe, $\$$ 6 \& 42 (M. Ott ed., 1874). See also K. Kaltenborn, Kritik Des VÖLKERRECHTS 193 (1847), recited from supra note 55, at 567.

82 M. Wright (ed.), The Theory and Practice of the Balance of Power: Selectted European Writings 116 (1975), recited from supra note 62 , at 600 .

83 R. Vincent, Nonintervention and International Order 45-54 (1974), recited from id. at 600. 
Such progressive scholars think of the balance of powers differently from those who accept it as being necessary for the benefits to international society as a whole rather than to hegemonic powers alone. In short, scholars of the former school view the system as nothing more than a means for hegemonic powers to justify their selfserving interventions in weaker States' affairs, while those of the latter school hold that the balance of power serves the common good as a pillar of international law.

The case study of the Triple Intervention thus makes clear the alignment of the critical attitude towards the balance of power with the perspective of realpolitik. The public declarations of States are, so to speak, less realistic than their actions. From this perspective, the European approach to the power balance does not justify the Triple Intervention under international law.

\section{Strong Nationalism Afterward: "Only Might Made Right!"}

Japan considered the Triple Intervention a humiliating blow to its hope and pride, especially coming after a period in which the entire nation had been delirious with victory, ambitions and expectations. ${ }^{84}$ Both people and the governing classes in Japan had such sentiment that the terms of the peace should both spare China humiliation, and guarantee China's subservience to Japan for years to come. As a result, Japan wanted to prevent hostilities between the two countries and China's interference in Korea. $^{85}$

In addition, Japan considered the war with China a demonstration to the Western powers of its civilization, its international law-abiding spirit, and its sovereignty in international affairs following years of unequal treaties. ${ }^{86}$ On July 16, 1894, Japan signed its first equal treaty with the UK. Article 20 of this treaty stipulates that the privileges and immunities of British subjects under the former unequal treaties should be abolished when it enters into force. ${ }^{87}$ Other Western powers subsequently

84 Munemitsu, supra note 5, at 252.

85 Doc 545, 6706/303, Despatch from Mr. Trench to the Earl of Kimberley, Subject: Japan and Liaotung Peninsula, 21 April 1895, in BRITISH DocumenTs, supra note 2, at 308.

86 D. Howland, Japan's Civilized War: International Law as Diplomacy in the Sino-Japanese War (1894-1895), 9 J. HIST. INT'L L. 181-9 \& 198-201 (2007). See also Junnan Lai, Sovereignty and 'Civilization': International Law and East Asia in the Nineteenth Century, 40 MoD. CHINA 297-303 (2014).

87 For the text of the Anglo-Japanese Treaty of Commerce and Navigation, see C. PARRY (ED.), The Consolidated TREATY SERIES (vol. 180) 257 (1969), recited from Yoshiro Matsui, Modern Japan, war and international law, in JAPAN AND 
concluded similar fairly equal treaties with Japan in the future. ${ }^{88}$ Japan thus believed that its goal would be coming to pass as the European powers did. The Triple Intervention, however, proved that this conclusion was premature, because Japan still lacked the military strength to ignore the powers' implicit threats when it came to vital national security issues. ${ }^{89}$ The public was not able to accept what had happened. Mutsu addressed:

Imagine how chagrined the public would have felt if the peace treaty had omitted that one clause relating to the cession of the Liaotung Peninsula, an area taken at the cost of so much Japanese blood! The nation's feelings might well have run beyond chagrin. ${ }^{90}$

After the Sino-Japanese War, the Western powers showed that they did not care about moral issues, let alone the traditional concerns of Confucian ethics, ${ }^{91}$ but only gave priority to the precepts that "might makes right"; that national survival could only be guaranteed through military strength and aggressive nationalism. ${ }^{92} \mathrm{Mr}$. Hayashi, during a meeting with Mr. Trench, affirmed that Japan would now have to devote itself to increasing its naval power so that its fleet would be around one-tenth the size of the UK's. ${ }^{93}$

In its post-1895 military build-up, Japan increased the size of its army by six divisions, providing its soldiers with new and better equipment and adding many new ships and men to its navy. Therefore, the military began to receive increasing support from Japanese society, thanks in part to the proliferation of patriotic and fiercely nationalistic societies dedicated to the expansion of Japanese territory. ${ }^{94}$ The mood of bitterness and disenchantment in Japan following the Triple Intervention was expressed in popular "Song of Diplomacy.","95

\footnotetext{
International Law: Past, Present and Future. International Symposium to Mark the Centennial of the Japanese Association of International Law 10 (Nisuke Ando ed., 1999).

88 I. Nish, Japanese Foreign Policy 1869-1942: Kasumigaseki to Miyakezaka $46-50$ (1977). See also James L. McClain, JAPAn, A Modern History 299 (2002).

89 Supra note 3, at 290.

90 Munemitsu, supra note 5, at 252.

92 F. Iklé, The Triple Intervention: Japan's Lesson in the Diplomacy of Imperialism, 22 Monumenta NIPPONICA 129 (1967).

93 Doc 649, 6706/393, Despatch from Mr. Trench to the Earl of Kimberley, Subject: Three-Power Intervention, 6 May 1895, in BRITISH DOCUMENTs, supra note 2, at 363.

94 Supra note 92, at 130. See also D. Brown, Nationalism in Japan: An Introductory Historical Analysis 133 (1955).

95 The song reads: "In the West there is England, In the North, Russia. My countrymen, be careful! Outwardly they make treaties, but you cannot tell. What is at the bottom of their hearts. There is a Law of Nations, it is true, But when the moment comes, remember, The Strong eat up the Weak." See supra note 92, at 130. See also G. SANSOM, THE WESTERN
}

91 Id. at 293. 
Similarly, editors of the newspaper Jiji Shinpo 时事新报, in an article with the headline "Wait for another time," advised their readers that "they must not forget that justice and sentiment find no place in modern diplomacy, but that all questions are in practice solved by mere brute force." ${ }^{, 96}$ Another publication, Shinbun 日日新闻 likewise concluded that "for diplomatic success, the prime necessity is a sufficiency of military strength."

The Triple Intervention did not put an end to Japan's efforts to be a predominant power in East Asia. Only two years later, the Russo-Japanese War broke out. Also, the German-French-Russian alliance even prompted Japan to enter World War I on the side of the British. The Russo-Japanese War ended in 1905 with the Treaty of Portsmouth. ${ }^{98}$ Following the treaty, Russia recognized Korea as part of the Japanese sphere of influence (Article 2); agreed to evacuate Manchuria (Article 3); and signed over its 25-year leaseholder rights to Port Arthur, including the naval base and the peninsula around it, and ceded the southern half of Sakhalin Island to Japan (Article 5). Japan thereby reversed the outcome of the Triple Intervention and secured a large foothold on the Asian mainland..$^{99}$ In 1914, during World War I, Japan occupied the German-leased territory of Kiaochow and forced the German base at Tsingtao to surrender. ${ }^{100}$

In 1915, Japan presented China with the Twenty-One Demands, ${ }^{101}$ which were categorized into five groups. The first was to ensure Japan's predominant position in the Shantung Province that Germany had held before the war. The second was to maintain Japan's favored position in South Manchuria and Eastern Inner Mongolia. The third was to secure mining and railway concessions in central harbors, bays, and islands along the Chinese coast. The fourth was to bar China from granting any further concessions relating to coastal or island territory to any foreign power except Japan. The fifth was to hire Japanese advisors for China to take effective control of

World and Japan: A Study in the Interaction of European and Asiatic Cultures 406 (1950).

96 The Spirit of the Vernacular Press during the Week, in The JAPAN WeEkly MaIL (YoKohama), May 11, 1895, at 522, recited from supra note 3 , at 290 .

97 Id. at 291.

98 See Treaty of Portsmouth ending the Russo-Japanese War, WWI Document Archive website, available at http://wwi. lib.byu.edu/index.php/Treaty_of_Portsmouth_ending_the_Russo-Japanese_War (last visited on Nov. 1, 2018).

99 Supra note 33 , at 178.

100 Nish, supra note 88, at 93-97.

101 The Twenty-One Demands (Japanese: 対華21 ヶ条要求, Taika Nijūikkajō Yōkyū, simplified Chinese: 二十一 条; traditional Chinese: 二十一條; pinyin: Ėrshíyī tiáo). The text of the demands is given in Y. WANG, SIXTY YEARS Between China and Japan (vol. 6) 73-7 (1980) < available only in Chinese>. See also Zhongri "ErshiYitiao" JiaOshe Shiliao Quanbian 670-8 (J. Huang ed., 2001) < available only in Chinese>. 
both its finances and police force. ${ }^{102}$ Japan seemed to have taken back in the $1910 \mathrm{~s}$ over, what the three powers-Russia, France and Germany, had been 'recompensed' by China for their efforts in the Triple Intervention. ${ }^{103}$

\section{Conclusion: A Reflection on the Triple Intervention}

In the nineteenth-century international law, the First Sino-Japanese War might be depicted as a clash between barbarism and civilization. Although many Western international legal documents spoke highly of Japan's actions during the war, it was nonetheless forced to give up a large part of the gains promised in the Treaty of Shimonoseki. The Triple Intervention protected Chinese and Korean independence, thereby maintaining regional peace shortly. However, various powers intervened in this course in order to pursue their own goals and aggrandizement. Faced with threats of force-albeit issued in the form of friendly advice-from the so-called civilized States, Japan had no choice but to view military strength as the deciding factor in international relations.

Following the Triple Intervention Japanese society was moving toward chauvinism and expansionism. Japan began strengthening its military power to fight back. The intervention remained a wound for generations. Hirohito mentioned it when Japan surrendered at the end of World War II, as did General Ishiwara Kanji when challenging an American prosecutor at the Tokyo war-crimes trials in 1946, along with another humiliation suffered by Japan:

Haven't you heard of [U.S. Commodore Matthew] Perry? Don't you know anything about your country's history? ... Tokugawa Japan believed in isolation; it didn't want to have anything to do with other countries and [it] had its doors locked tightly. Then along came Perry from your country in his black ships to open those doors; he aimed his big guns at Japan and warned, "If you don't deal with us, look out for these; open your doors, and negotiate with other countries too." And then when Japan did open its doors and tried dealing with other countries, it learned that all those countries were a fearfully aggressive lot. And so for its own defense it took your country as its teacher

102 W. Chamberlin, Japan over Asia 86 (1938). See also Nish, supra note 88, at 98.

103 The Soviet Union took back Port Arthur and the southern half of Sakhalin Island later following the defeat of the Japanese in World War II by the Yalta Agreement on February 11, 1945 signed between the leaders of the Soviet Union, the US and the UK. See Yalta Agreement, National Diet Library, available at http://www.ndl.go.jp/constitution/ e/etc/c04.html (last visited on Nov. 2, 2018). 
and set about learning how to be aggressive. You might say we became your disciples. Why don't you subpoena Perry from the other world and try him as a war criminal? ${ }^{104}$

Japans interactions with the West shows its notions of the then civilization. From the Japanese perspective, military strength should be considered a fundamental aspect of Western civilization - one housed, if paradoxically, within the context of international law. Or the nineteenth century's conception of international law had to be considered somehow incomplete - failing as it did to account for Western States' actual practices or for Japan's experience with the Triple Intervention.

The First Sino-Japanese War is no mere historical curiosity, because it still has relevance to the development of international law as it is practiced today. Van der Linden said that, in order to progress, "international law must be reconciled with its past" and "international legal doctrine should become aware of its nineteenthcentury burden." ${ }^{, 105}$ Positivist international law defines a State based on a population on a specific territory with an effective government. ${ }^{106}$ Such a definition regards countries as political and juridical entities while disregarding their citizens as acting subjects. So, positivist international law disregards Japan's suffering and its collective memory of international law in the 19th century. The Triple Intervention has shown that nationalism played an essential role in shaping a State's identity, which resides primarily in its collective memory. In this respect, positivist international law would reveal its ahistorical perspective, because nationalism exists regardless of its acknowledgement in legal terms.

Furthermore, this case study affirmed the arguments of critical international legal theorists that international law was a tool of colonialism which have been often manipulated by hegemonic States in the guise of civilization and for the service of power politics. Legal realism and critical legal studies maintain that State practices are mere expressions of power politics. However, the historical argument presented here addresses States' subjective beliefs. The positivist approach would interpret State as abstraction or institution without its own mind. ${ }^{107}$ In this regard, positivist international lawyers would believe that the decision-making process or diplomatic negotiations are so closed and secret that it is impossible for any legal

\footnotetext{
104 Supra note 33, at 173.

105 M. Linden, The Acquisition of Africa (1870-1914): The Nature of International Law 17 (2016).

106 Montevideo Convention on the Rights and Duties of States, Taiwan Documents Project Website, available at http:// www.taiwandocuments.org/montevideo01.htm (last visited on Nov. 2, 2018). See also M. Shaw, InTERnational LaW 178 (2003).

107 T. Hillier, Sourcebook on Public International Law 81 (1998).
} 
method to observe the consciousness of a modern, bureaucratic State ${ }^{108}$ Given that the psychological element of custom cannot be searched and detected, positivist international lawyers have attempted to save this deficiency by postulating legal authority, a move that critical legal theory does not accept. ${ }^{109}$ Martti Koskenniemi, for example, addressed the inevitability of political choices or preferences when legal authorities choose legal norms in constructing their legal arguments. ${ }^{110}$ He would finally raise questions to "the justification of adopting a certain interpretation of the meaning of State conduct." ${ }^{, 111}$ One of the criteria suggested by Koskenniemi to "distinguish a State's legal from its purely political behaviour" is to "look at the State's own self-understanding of the character of its action." ${ }^{, 12}$ This study has demonstrated that archival research can be of use in this sense by revealing the underlying beliefs and ideas of sovereign States. One implication of this demonstration is that international lawyers and diplomatic historians can be benefitted from exploring these aspects of States over long periods of time when attempting to explain their conduct in the present.

108 A. Carty and R. Smith, Sir Gerald Fitzmaurice and the World Crisis: A Legal Adviser in the Foreign Office 19321945, 24 (2000).

109 Rosalin Higgins says that the key feature that assures legality is that decisions are made by those who are authorised to take them. See R. Higgins, Problems and Process: International Law and How We Use It 9 (1994).

110 M. Koskenniemi, From Apology to Utopia: The Structure of International Legal Argument (Reissue with a new EpILOGUE) 601-2 (2006).

111 Id. at 174

112 Id. at 175 . 